on popular vote by counties from Scribner's Statistical Atlas (156-157) Schulten had already included.

Despite its fantastic content, this volume is marred by the typography and the page layout. Although the unidentified sans-serif type is very pleasing, the 10-point (or smaller) font size used throughout is very hard to read and is a definite challenge for anyone's eyesight. As well, the text-image proportions on any given page can vary considerably. Where some pages are packed with text, others are left with large, awkward, empty spaces-not unlike the blank areas found on many maps from the Age of Exploration! Of course, there is no need to fill these gaps with sea monsters, but the space could definitely have been used to add more map details, cartouches, symbols, or curiosities. Another problem, common to many other books with large illustrations, is that the maps are not adjusted to the page size. Frequently, the images are printed over the inside margin and across the gutter so that map details are lost in the crease, and the maps appear chopped or truncated, thus considerably spoiling the visual experience. For her 2012 book, Mapping the Nation, Schulten offered zoomable, high-resolution copies of all maps on a companion website, mappingthenation.com. Readers of $A$ History of America in $100 \mathrm{Maps}$, however, only have access to 15 map thumbnails on the publisher's promotion page, america100maps.com.

In summary, Schulten does exactly what she promises at the beginning of her book: provide a visual tour through American history, supported by maps. History, in this case, is not written with a capital $\mathrm{H}$, but is instead conceived as a collection of individual stories, with each map having its own to tell. Reading $A$ History of America in 100 Maps is certainly a nice way to learn about the United States of America's past and the fascinating parts mapmaking has played in that history.

\section{REFERENCES}

Baynton-Williams, Ashley. 2015. The Curious Map Book. Chicago: University of Chicago Press.

Brooke-Hitching, Edward. 2018. The Phantom Atlas: The Greatest Myths, Blunders and Lies on Maps. San Francisco: Chronicle Books.

Harley, J. B. 1990. "Text and Context in the Interpretation of Early Maps." In From Sea Charts to Satellite Images: Interpreting North American History Through Maps, edited by David Buisseret, 3-15.

Chicago: University of Chicago Press.

Howells, Tom, and Duncan McCorquodale, eds. 2010. Mapping America. Exploring the Continent. London: Black Dog Publishing.

Mason, Betsy, and Greg Miller. 2018. All Over the Map: A Cartographic Odyssey. Washington, DC: National Geographic.

Robinson, Anthony. 2019. "Elements of Viral Cartography." Cartography and Geographic Information Science 46 (4): 293-310. doi: 10.1080/15230406.2018.1484304.

Schwartz, Seymour, and Ralph Ehrenberg. 1980. The Mapping of America. New York: Harry N. Abrams.

Schulten, Susan. 2001. The Geographical Imagination in America, 1880-1950. Chicago: University of Chicago Press.

Schulten, Susan. 2012. Mapping the Nation: History and Cartography in Nineteenth-Century America. Chicago: University of Chicago Press.

Smithsonian Institution. 2018. History of the World Map by Map. New York: DK Publishing.

\title{
GIS TUTORIAL FOR CRIME ANALYSIS, SECOND EDITION
}

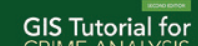

GIS Tutorial for
CRIME ANALYSIS

: $2.0 \%$

ini

anos

By Wilpen L. Gorr, Kristen S. Kurland, and Zan M. Dodson

Esri Press, 2018

348 pages, $\$ 84.99$, soft cover.

ISBN: 978-1-58948-516-7

Review by: Janet Tennent, Montgomery College
GIS Tutorial for Crime Analysis is a workbook designed for use by police forces interested in leveraging the power of GIS in various aspects of their work. Through the use of such tools, police organizations can turn raw data into useful information products, mapping incident reports, crime statistics, and modeled prediction scenarios. Analysis of the locations where crimes have occurred, and where contributing conditions and phenomena intersect, can lead to 
more accurate predictions of developing or future crime patterns. This in turn can assist in planning for resource allocation-allowing police forces to move their officers from lower crime areas to places they may be more urgently needed. GIS can also be used as a community outreach tool for showing the public what their police forces are doing, and helping educate both neighborhood watch committees and individual citizens about what they can do to help protect themselves.

The book is geared toward the GIS beginner, but readers will still find having some GIS background very helpful. Most chapters feature two or three thematic scenarios followed by two or more Tutorials and a couple of Assignments each. The tutorials give step-by-step explanations for each of the scenarios covered, and also provide examples of the sort of results one should expect when performing, say, an attribute query. The assignments present similar tasks in a more "your turn now" manner, without the hand-holding. If the book were to be used as a classroom text, these assignments could easily become homework tasks to be handed in for grading. As with any other GIS book or tutorial, it is always best to complete all the steps in order.

The numerous maps and diagrams throughout the book are very helpful-especially for an individual without a GIS background-and can be used as a measuring stick that allows the reader to confirm that they are correctly completing and understanding the steps.

GIS Tutorial for Crime Analysis shows several ways that GIS can be applicable to police work. It introduces the basics of GIS to the neophyte, and is a great review for the GIS student going into the law enforcement field. I was taking my first course in GIS at the same time I was reviewing this book, and for the most part I had no problems or difficulties following it. I found each of the scenarios very interesting. I did find it a little disappointing, however, that in working through the Chapter 7 "Geocoding crime incident data" exercises, ArcMap would crash at various points-during both the Tutorial and Assignment segments. I retried the steps several times, and the same crashes would happen again and again. Some advanced GIS students in my school have since told me that they experience the same or similar problems with ArcMap in their coursework. It is not clear if this is a bug in the ArcMap program, or if the problem is in the tutorial, but either way, it disrupts the learning process.

Software problems aside, GIS Tutorial for Crime Analysis, Second Edition is a useful and usable resource for anyone interested in using GIS for crime analysis and police work. It explains the what and the why, and shows the how, of building a crime-analysis system, and it does so from the ground up for a reader with minimal pre-existing GIS skills.

\section{A DIRECTORY OF CARTOGRAPHIC INVENTORS: CLEVER PEOPLE AWARDED A US PATENT FOR A MAP-RELATED DEVICE OR METHOD}

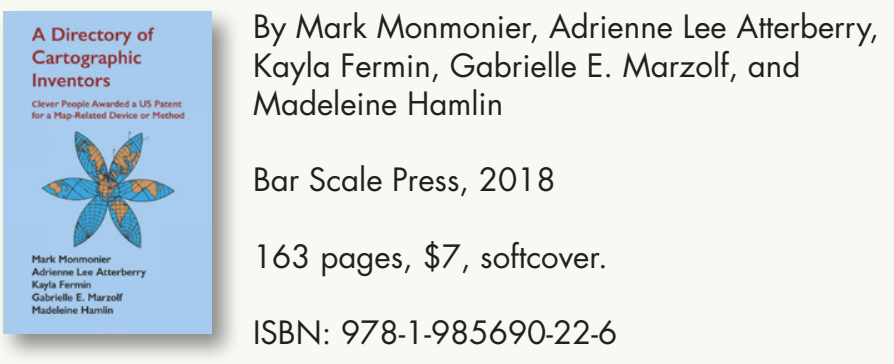

Review by: Trudy Suchan

A Directory of Cartographic Inventors provides biographical information about the cartographic patentees featured in Mark Monmonier's recently published Patents and Cartographic Inventions: A New Perspective for Map History (reviewed last year in Cartographic Perspectives 90). The
Directory is a resource that brings together and preserves much of the biographical research that underpinned, but did not make it into, Patents and Cartographic Inventions.

Where Patents and Cartographic Inventions is organized thematically around the inventions, $A$ Directory of Cartographic Inventors is a straight-up reference book with 31 biographies in alphabetical order. All but two of the patentees featured in the Directory's main section appear in Patents and Cartographic Inventions, as do all but three of the twenty-four additional inventors more briefly discussed at the back of the book.

The Directory covers a roughly two-hundred-year period between 1789 and 1995, from the birth of Silas Cornell 